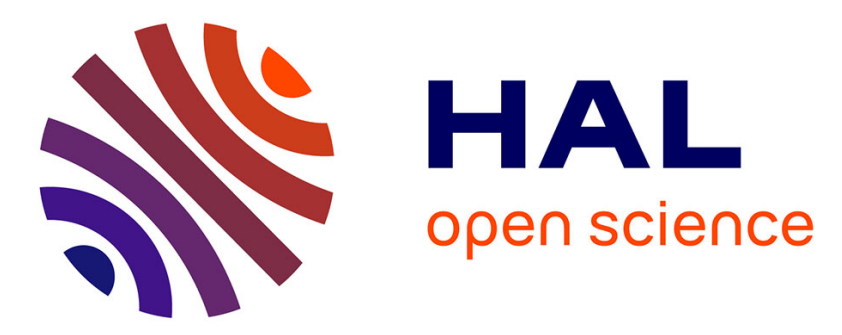

\title{
Between private and public law: The contribution of late medieval ius commune to the conceptualisation of diplomatic representation
}

Dante Fedele

\section{- To cite this version:}

Dante Fedele. Between private and public law: The contribution of late medieval ius commune to the conceptualisation of diplomatic representation. Clio@Thémis. Revue électronique d'histoire du droit, 2020, 18, pp.1-16. 10.35562/cliothemis.304 . hal-02881314

HAL Id: hal-02881314

https://hal.univ-lille.fr/hal-02881314

Submitted on 25 Jun 2020

HAL is a multi-disciplinary open access archive for the deposit and dissemination of scientific research documents, whether they are published or not. The documents may come from teaching and research institutions in France or abroad, or from public or private research centers.
L'archive ouverte pluridisciplinaire HAL, est destinée au dépôt et à la diffusion de documents scientifiques de niveau recherche, publiés ou non, émanant des établissements d'enseignement et de recherche français ou étrangers, des laboratoires publics ou privés. 


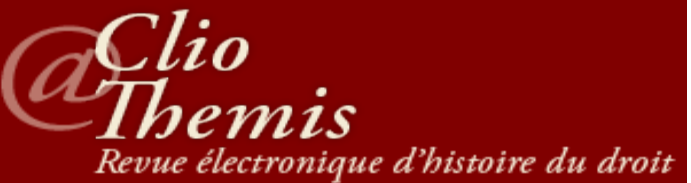

\title{
Between private and public law : The contribution of late medieval ius commune to the conceptualisation of diplomatic representation
}

\begin{abstract}
This paper examines the development, by late medieval ius commune jurists, of a notion of diplomatic representation which is rooted in the doctrine of private law agency. In particular, it endeavours to study the basis and limits of ambassadors' negotiating powers, by analysing some issues relating to procuration and the ratification of treaties. The conclusion illustrates the persistence of the central role of this notion of diplomatic representation in the discussion of the matter right up until the late eighteenth century, thus allowing us to appreciate the importance of the contribution made by late medieval ius commune to the early modern discussion of the status of the ambassador.
\end{abstract}

Résumé : Cet article examine l'élaboration, par les juristes du ius commune médiéval, d'une notion de représentation diplomatique qui plonge ses racines dans la doctrine de la représentation en droit privé. En particulier, il s'attache à étudier le fondement et les limites des pouvoirs de négociation de l’ambassadeur, par une analyse de quelques questions concernant la procuration et la ratification des traités. La conclusion montre que cette notion de représentation diplomatique joua un rôle central dans la discussion de la matière jusqu'à la fin du XVIII ${ }^{e}$ siècle, permettant d'apercevoir l'importance de la contribution apportée par le ius commune de la fin du Moyen Âge à la discussion sur le statut de l'ambassadeur au début de l'époque moderne.

Keywords: ius commune, diplomatic representation, negotiating power, ratification of treaties, private law analogies in international law

Mots clés : ius commune, représentation diplomatique, pouvoir de négociation, ratification des traités, analogies de droit privé en droit international

I. Since the publication, in 1927 , of Hersch Lauterpacht's doctoral dissertation, entitled Private law sources and analogies of international law, the idea that private law sources and analogies contributed much to the development of early modern and modern public international law has been well established in historiography'. Several studies have delved into the reception and adaptation of Roman private law, showing the extent to which its concepts, principles and rules have influenced modern international law (and treaty law in particular), and even how often it provided arguments and a source of inspiration for international legal practice during the second half of the twentieth century and the early twenty-first century ${ }^{2}$. In recent years, private law institutions such as occupation and acquisitive prescription have also

I See H.Lauterpacht, Private law sources and analogies of international law (with special reference to international arbitration), London, Longmans, Green and Co., 1927 [reprint London, Archon Books, 1970].

2 See especially K.-H. Ziegler, « Die römischen Grundlagen des europäischen Völkerrechts », Ius commune, 4, I972, p. I-27; C. Baldus, Regelhafte Vertragsauslegung nach Parteirollen im klassischen römischen Recht und in der modernen Völkerrechtswissenschaft, 2 vol., Frankfurt am Main et al., Peter Lang, 1998; and R. Lesaffer, « Argument from Roman Law in Current International Law : Occupation and Acquisitive Prescription », The European Journal of International 
been studied in relation to the notion of empire in Western legal and political thought and to the ideological context of European imperialism?. The function of private law sources and analogies in late medieval scholarship on public international law has, however, received much less attention ${ }^{4}$. The purpose of this paper is to shed light on this function by analysing the impact of late medieval scholarship on private law agency on the conceptualisation of diplomatic representation, in the broader context of a discussion of the significance of late medieval legal scholarship for the elaboration of the status of ambassadors's. After providing some introductory remarks on the origins of the debate on the office of ambassador, this paper examines the definition of the basis and limits of the negotiating power granted to diplomatic envoys in the late medieval ius commune. The conclusion will illustrate with some examples the persistence of this notion of diplomatic representation in the juristic discussion of the matter right up until the late eighteenth century.

\section{The office of ambassador in the late medieval ius commune}

2. In Northern and Central Italy, the practice of diplomacy developed significantly over the twelfth century, in parallel with the growth of the communes. The Lombard League - formed in ${ }_{1} 67$ as a military and defensive alliance against Frederick I and his attempts to curtail the freedoms of the communes played a major role in the strengthening of a close web of relations between its member cities, and greatly influenced their institutional evolution through the creation of supra-city institutions and the establishment of shared rules of mediation and political communication ${ }^{6}$. The Roman Church - which began to dispatch emissaries and legates as early as the fourth century - had also relied heavily on papal legates since the late eleventh century, in its endeavours to centralize political and administrative power ${ }^{7}$. A great difference, however, existed between papal legates and secular ambassadors : the former were agents empowered by the pope with public authority - the power to « govern » a province, in the words of Bernardus Papiensis (d. I213) and later of Henricus de Segusio (Hostiensis, c. I200-127I), « iurisdictio, sive potestas 》 in those of Guillaume Durand (1236-1296), and even «imperium » in those of Baldus de Ubaldis (1327-I400) ${ }^{8}$. In other words, papal legates were primarily sent out not to negotiate an agreement,

Law, 16 (I), 2005 , p. $25-58$.

3 See A. Fitzmaurice, Sovereignty, Property and Empire, 1500-2000, Cambridge, Cambridge University Press, 20I4; and E. Cavanagh, « Prescription and Empire from Justinian to Grotius », The Historical Journal, 6o (2), 2017, p. $273-299$.

4 Exceptions include K.-H. Ziegler, «The Influence of Medieval Roman Law on Peace Treaties », in Peace Treaties and International Law in European History, ed. R. Lesaffer, Cambridge et al., Cambridge University Press, 2004, p. I47-I6I ; and - of particular importance for the present article - D.E. Queller, The Office of Ambassador in the Middle Ages, Princeton, N.J., Princeton University Press, 1967. The need to closely study late medieval legal scholarship « to understand the impact of Roman law on the modern law of nations during its "formative period" ( $16^{\text {th }}-17^{\text {th }}$ centuries) $)$ has been emphasised by R. Lesaffer, « Argument from Roman Law » (note 2), p. 35-38.

5 For a fuller discussion of the latter issue, see D.E. Queller, The Office of Ambassador (note 4); D. Fedele, « The status of ambassadors in Lucas de Penna's Commentary on the Tres Libri », Tijdschrift voor Rechtsgeschiedenis, 84, 2016, p. 165-192 ; and Idem, Naissance de la diplomatie moderne (XIII-XVII' siècles). L'ambassadeur au croisement du droit, de l'étbique et de la politique, Baden-Baden/Zürich/St Gallen, Nomos Verlag/Dike Verlag, 2017.

6 On the Lombard League, see G. Vismara, «Struttura e istituzioni della prima Lega Lombarda » (1970), in Id., Scritti di storia giuridica, 3, Istituzioni lombarde, Milan, Giuffrè, 1987, p. 15-68; and G. Raccagni, The Lombard League II67-I225, Oxford, Oxford University Press, 2oIo. On the development of inter-city relations, see M. Vallerani, «I rapporti intercittadini nella regione lombarda tra XII e XIII secolo », in Legislazione e prassi istituzionale nell'Europa medievale. Tradizioni normative, ordinamenti, circolazione mercantile (secoli XI-XV), ed. G. Rossetti, Naples, Liguori, 200I, p. 22I290.

7 See K.R. Rennie, Law and Practice in the Age of Reform. The Legatine Work of Hugh of Die (I073-II06), Turnhout, Brepols, 2oro, and, on papal diplomacy in the early Middle Ages, Id., The Foundations of Medieval Papal Legations, Basingstoke and New York, Palgrave Macmillan, 2013, and P. Blet, Histoire de la Représentation Diplomatique du Saint Siège des origines à l'aube du XIX' siècle, Città del Vaticano, Archivio Vaticano, 1982.

8 See Bernardus Papiensis, Summa Decretalium, ed. E.A.T. Laspeyres, Ratisbonae, apud G. Iosephum Manz, I86o, liber I, tit. 22 (De officio legati), $\$ \mathrm{I}-2$, p. I8 (《Legatus dicitur, cui aliqua patria vel provincia regenda committitur, ut eius vice fungatur, a quo destinatur. [...] Sane de causis, quae pertinent ad iurisdictionem iudicum, qui sunt in sua provincia, cognoscere et diffinire potest $\gg)$; Henricus de Segusio, Summa aurea, Venetiis, L.A. Giunta, I574, liber I, tit. De officio 
but to exercise jurisdiction in territories which were subject to the pope's (spiritual, at least) sovereignty'. The ambassadors exchanged between Italian cities, on the other hand, had no such authority : since they operated beyond the territorial limits of their principal's jurisdiction, they had no power to oblige the recipient of their mission to do anything and were solely authorised to deliver a message, or to negotiate as best they could to achieve their principal's goals. Even agents exchanged between the emperor and cities could be considered simple ambassadors by legal scholars, as is shown by two comments in which Odofredus Denariis (d. I265) mentions Frederick I and the Lombards' « ambasiatores » who engaged in the negotiations which led to the Peace of Constance (II83) ${ }^{\text {ro }}$.

3. The intense diplomatic activity that characterised Northern and Central Italy caused jurists to start pondering the office of ambassador from the late twelfth century onwards, even before local statutes began to establish a regulatory framework for diplomatic activities (which, in any case, throughout the late Middle Ages was always far from being complete) ${ }^{\text {II }}$. One of the main questions upon which the jurists focused was the public role assigned to the ambassador (legatus), referred to by the terms officium and munus publicum. The latter in particular, rooted in the Roman system of the munera - the public services which Roman citizens had to perform for their municipium - indicated the compulsory nature of the office, which (with certain exceptions) had to be fulfilled by the person appointed for as long as had been stipulated $^{12}$. Other aspects of the office that were discussed by late medieval jurists include the range of actors entitled to send ambassadors, the ambassador's appointment, his right to a salary or reimbursement for the losses incurred during his mission, his capacity to accept or solicit gifts and benefices from the recipient of his mission, and his inviolability, immunities and other privileges ${ }^{13}$. The definition of the (public) status of the ambassador was, moreover, linked to that of the cities themselves. As is well known, Roman law defined cities as municipia and, reserving the status of respublica only to Rome, considered them to be mere private entities ${ }^{14}$. It is noteworthy that one of the first legal works to elaborate on the status of ambassadors, the Summa Trium Librorum written by the Tuscan judge and advocate Rolandus

legati, col. 317, n. I (« Hic tamen specialiter tractatur de legatis Apostolicae sedis quibus aliqua terra, seu provincia regenda committitur »); Guillelmus Durandus, Speculum iudiciale, Basileae, Froben, 1574 [reprint Aalen, Scientia Verlag, 1975], liber I, particula I, tit. De legato, $\S \mathrm{I}$, p. 30a, n. I ( Nos tamen hic principaliter de illo legatorum genere tractare intendimus, quibus a sede Apostolica certa provincia gubernanda mandatur »); Baldus de Ubaldis, In primam Digesti Veteris partem Commentaria, Venetiis, [Società dellaquila che si rinnova], I599 [reprint Goldbach, Keip Verlag, 2004], ad Dig. I.I6.7.2, fo 6rvb, n. 3 (《legati de latere [...] habent [...] iurisdictionem [...] maiorem omnibus post Principem »); and Baldus de Ubaldis, In Decretalium Volumen Commentaria, Venetiis, L.A. Giunta, I595 [reprint Turin, Bottega d'Erasmo,

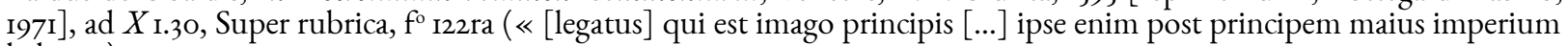
habet $\gg)$.

9 See R. Schmutz, « Medieval Papal Representatives : Legatus, Nuncius, and Judges », Studia Gratiana, I5, 1972, p. 443-463; K. Pennington, «Johannes Teutonicus and papal legates » (1983), in Id., Popes, Canonists and Texts, II50-I550, Ashgate, Aldershot 1993; R.C. Figueira, «The Classification of Medieval Papal Legates in the Liber Extra », Archivum Historiae Pontificiae, 2I, I983, p. 2II-228 ; Id., «"Legatus apostolicae sedis": the Pope's "alter ego" According to Thirteenth-Century Canon Law », Studi Medievali, 27 (2), 1986, p. 527-574; and Id., «The Medieval Papal Legate and his Province: Geographical Limits of Jurisdiction », Apollinaris, 6I, 1988, p. 817-860.

Io See Odofredus, Lectura super Digesto Veteri I, Lugduni, Excudebant Petrus Compater, \& Blasius Guido, I550, ad Dig. 2.I.I2, fo $40 \mathrm{ovb}$, n. 2 ; and ibidem, ad Dig. 2.I.I4, fo 4 Ira, n. I. See G. Raccagni, « When the Emperor Submitted to his Rebellious Subjects: A Neglected and Innovative Legal Account of the Peace of Constance, II83 », English Historical Review, 131, 2016, p. 519-539.

II On local statutes, see the overview by P. Gilli, « Ambassades et ambassadeurs dans la législation statutaire italienne (XIII'$\mathrm{XIV}^{\circ}$ siècle) $\gg$, in De l'ambassadeur. Les écrits relatifs à l'ambassadeur et à l'art de négocier du Moyen Age au début du $X I X^{e}$ siècle, ed. S. Andretta, S. Péquignot and J.-C. Waquet, Rome, École française de Rome, 20I5, p. 57-85, with further references.

I2 See Dig. 50.4.I8, which reports the systematisation of munera civilia seu publica by Arcadius Charisius (third-fourth centuries CE) : munera personalia (Dig. 50.4.I8.I-I7, which include legationes ad sacrarium principis), munera patrimonii (Dig. 50.4.18.18-25) and munera mixta (Dig. 50.4.18.26-27). Previous classifications by Ulpian and Hermogenian had only distinguished between munera personalia and munera patrimonii: see Dig. 4.6.3-5 and Dig. 50.4.I.3, respectively. On the notion of munus publicum, see F. Grelle, «Munus publicum. Terminologia e sistematiche » (196I), in Id., Diritto e società nel mondo romano, ed. L. Fanizza, Rome, L"Erma" di Bretschneider, 20o5, p. 39-64 ; L. Neesen, «Zur Entwicklung der Leistungen und Ämter (munera et honores) im römischen Kaiserreich des zweiten bis vierten Jahrhunderts », Historia, 30, 1981, p. 203-235; F. Millar, «Empire and City, Augustus to Julian : Obligations, Excuses and Status », The Journal of Roman Studies, 73, 1983, p. 76-96; N. Lewis, The compulsory public services of Roman Egypt, Florence, Gonnelli, 1997 ; and G. Pereira-Menaut, « Che cos'è un munus ? », Athenaeum, 92 (I), 2004, p. I69-215.

13 See D. Fedele, Naissance de la diplomatie moderne (note 5), p. II9-174, with further references. 
de Lucca in II95-I197, and then revised until the I230s, is also among the first works in which the public nature of cities was strongly asserted. This was indeed a pioneering claim, which as late as the second half of the thirteenth century would still not be unanimously accepted in legal scholarship ${ }^{15}$.

4. Over time, a substantive body of jurisprudence grew out of this reflection, to which all three branches of late medieval ius commune - i.e. Roman, canon and feudal law - greatly contributed. As well as being a supra-national legal system, the ius commune was also at the core of legal education, providing a common language and a common form of legal reasoning. The sixth-century compilation of Roman law ordered by Emperor Justinian and the several compilations of canon law circulating in the late Middle Ages (namely Gratian's Decretum of c. II40, the Liber Extra of 1234, the Liber Sextus of 1298 and the Clementinae of I3I4) were authoritative legal texts extensively commented upon by legal scholars; although they consisted mostly of Lombard laws and customs, the Libri feudorum or Consuetudines feudorum included imperial laws too, and - since they formed part of the last volume of the Corpus iuris civilis (the Volumen) - also generated a stream of scholarly interpretation ${ }^{16}$. These texts, however, included only a handful of sections that dealt with « public international law » issues as such ${ }^{17}$ : this lacuna may contribute to explaining why « public international law » did not develop in the late Middle Ages as a distinctive branch of legal scholarship, with its own literature and method. And so, although jurists wrote extensively on matters of diplomacy, treaties, war and peace, they were obliged to elaborate the concepts, principles and rules governing these matters based on the adaptation of those that regulated other (often private law) issues, or by referring to explicit or underlying general legal principles ${ }^{18}$. The following discussion aims to illuminate this process through one specific example, the adaptation to the (public) office of the ambassador of concepts, principles and rules originally elaborated for private law agency.

5. Before turning to this discussion, however, it must be pointed out that, although the abovementioned body of jurisprudence was being generated by legal scholars working in universities, it was far from being just bookish law, unrelated to actual practice. As their biographies amply demonstrate, legal scholars not only held positions at university but were also actively engaged in the social and political life of their time,

I4 See in particular Dig. 50.16.15: «Bona civitatis abusive "publica" dicta sunt : sola enim ea publica sunt, quae populi Romani sunt »; and Dig. 50.16.16 : «Eum qui vectigal populi Romani conductum habet, "publicanum" appellamus. Nam "publica" appellatio in compluribus causis ad populum Romanum respicit : civitates enim privatorum loco habentur ».

I5 On the discussion about the public nature of the cities, see E. Conte, « Respublica. Il modello antico, la politica e il diritto nel XII secolo », in Iuris historia. Liber Amicorum Gero Dolezalek, ed. E. Conte and V. Colli, Berkeley, University of California at Berkeley, 2008, p. 193-212, with further references. Rolandus' Summa can be read in the critical edition by E. Conte and S. Menzinger, La Summa Trium Librorum di Rolando da Lucca (II95-I234). Fisco, politica, scientia iuris, Rome, Viella, 2012: in the section de legationibus (Cod. 10.65) of his Summa, Rolandus mentions his own diplomatic experience, referring to embassies carried out for the commune of Lucca, ibid., p. 240, n. 57. On Rolandus' « public career », see the biographical notes by V. Bagnai Losacco and F. Theisen ibid., p. XXVII-XLI, especially p. XXXVIII.

I6 See M. Bellomo, The Common Legal Past of Europe I100-I800 (1988), transl. L.G. Cochrane, Washington, D.C., The Catholic University of America Press, 1995 .

I7 In Roman law, see Dig. 49.I5 (De captivis et de postliminio et redemptis ab hostibus), Cod. 8.5o (De postliminio et de redemptis ab hostibus), Dig. 49.16 and Cod. 12.35 (both entitled De re militari); Dig. 50.7 and Cod. 10.65 (both entitled De legationibus) were interpreted by medieval scholars as referring to ambassadors, although the term legatus in these sections mostly referred to an internal agent appointed to connect the cities or provinces of the empire with its centre : see A. Gillett, Envoys and Political Communication in the Late Antique West, 4I-533, Cambridge et al., Cambridge University Press, 2003, p. 6, 9-10, and 22-23; W. Eck, « Diplomacy as Part of the Administrative Process in the Roman Empire », in Diplomats and Diplomacy in the Roman World, ed. C. Eilers, Leiden/Boston, Brill, 2009, p. 193-207; and F. Hurlet « Les ambassadeurs dans l'Empire romain. Les légats des cités et l'idéal civique de l'ambassade sous le Haut-Empire », in Ambassadeurs et ambassades au cour des relations diplomatiques. Rome - Occident Médiéval - Byzance (VIIIe s. avant J.C. - XII e s. après J.-C.), ed. A. Becker and N. Drocourt, Metz, Centre de recherche universitaire lorrain d'histoire, 20I2, p. IOI-I26. In canon law, C. 23 in Gratian's Decretum was devoted to war, and $X_{\mathrm{I} .34}$ was entitled De treuga et pace. To a lesser extent, some sections in the Libri feudorum were also relevant to questions of international law : see $L F 2.27$ (De pace tenenda, et ejus violatoribus), LF 2.28 (Hic finitur lex. Deinde consuetudines regni incipiunt) and LF 2.53-54 (De pace juramento firmanda. servanda, tuenda et vindicanda et de poena judicibus apposita, qui eam vindicare et justitiam facere neglexerint).

I8 See R. Lesaffer, « Roman Law and the Intellectual History of International Law », in The Oxford Handbook of the Theory of International Law, ed. A. Orford and F. Hoffmann, Oxford, Oxford University Press, 2016, p. 38-58: 45-51. 
as diplomats, public administrators, or sitting in either ecclesiastical or secular courts ${ }^{19}$. The legal science they elaborated was largely informed by this experience, which meant that their interpretations of the legal texts were effective adaptive responses to contemporary practical needs. The extent to which this legal science permeated late medieval society has recently been emphasised by Alain Wijffels, who defined it as a « science of public governance $»^{20}$. A clue to the pervasive influence of legal scholarship is provided by the enormous number of legal opinions (consilia) produced by jurists and preserved in manuscripts and printed editions : each of these opinions related to the solution of an actual case, which could concern not only private law litigations, but also inter-polity disputes and diplomatic issues ${ }^{21}$. As a result, although the notion of ius commune as « learned law » correctly conveys the idea of a body of law that was mainly elaborated by legal scholars in their interpretation of authoritative legal texts, it would be a mistake to understand this expression to imply that ius commune had little influence on the shaping of legal systems, or to dismiss it as barely relevant to actual practice ${ }^{22}$.

\section{The conceptualisation of diplomatic representation}

6. What defined an ambassador in the late Middle Ages ? In Western European diplomatic practice, an official envoy always carried a letter of credence, that is a formal document - written in Latin, and sealed and signed by the sender - addressed to the recipient of a mission, which the ambassador had to deliver at his first audience with his host. This letter did not usually explain the details - or even, sometimes, the general object - of the mission; its real function was to request the addressee to give full credence to the envoy or envoys' words, uttered on their sender's behalf. This document was the only prerequisite for the recognition of ambassadorial status ${ }^{23}$. An envoy might also carry other documents, but if his mission was simply to deliver a message, a letter of credence sufficed. Among the other documents that the ambassador might be carrying was an instruction, which was not essential - the use of verbal rather than written instructions was frequent - but became increasingly common from the thirteenth century on. Instructions were informal documents and intended for the envoy's eyes only : they told him what to do and say, and sometimes how to do or say it. They usually granted no power to bind the principal ${ }^{24}$. Until well into the twelfth century, there were two possible ways to conclude a negotiation : either the rulers

I9 With regard to the Italian context, see S. Menzinger, Giuristi e politica nei comuni di popolo. Siena, Perugia e Bologna, tre governi a confronto, Rome, Viella, 2006 ; and S. Menzinger and M. Vallerani, « Giuristi e città : fiscalità, giustizia e cultura giuridica tra XII e XIII secolo. Ipotesi e percorsi di ricerca », in I comuni di Jean-Claude Maire Vigueur. Percorsi storiografici, ed. M.T. Caciorgna et al., Rome, Viella, 20I4, p. 20I-234. For a later period, see L. Martines, Lawyers and Statecraft in Renaissance Florence, Princeton, NJ, Princeton University Press, 1968. Biographical references concerning many late medieval Italian jurists can be found in the Dizionario biografico degli italiani, Rome, Istituto dell'Enciclopedia italiana, 1960- (available at http://www.treccani.it/biografie) and in the Dizionario Biografico dei Giuristi Italiani (XII$X X$ secolo), ed. I. Birocchi et al., Bologna, Il Mulino, 2013.

20 See A. Wijffels, «Une très brève histoire du droit dans la civilisation occidentale (Iоoo-20oo) », Annales de Droit de Louvain, 77 (3), 2017, p. 397-4II : 397-398 : «Au Moyen Âge, lorsque la civilisation occidentale s'est forgée, le "droit" portait essentiellement sur une science de gouvernance publique. [...] [L]a science médiévale du droit portait sur l'ensemble de la gouvernance publique $\gg$. See also, Id., Introduction historique au droit. France, Allemagne, Angleterre, $3^{\text {rd }}$ ed., Paris, PUF, 2020, p. 2II-213.

2I See Consilia im späten Mittelalter. Zum bistorischen Aussagewert einer Quellengattung, ed. I. Baumgärtner, Sigmaringen, Jan Thorbecke Verlag, 1995; Legal Consulting in the Civil Law Tradition, ed. M. Ascheri, I. Baumgärtner and J. Kirshner, Berkeley, Robbins Collection, 1999, with further references; outside the late medieval Italian context, see also U. Falk, Consilia. Studien zur Praxis der Rechtsgutachten in der frühen Neuzeit, Frankfurt am Main, Vittorio Klostermann, 20o6, and W. Druwé, Loan and Credit in Consilia and Decisiones in the Low Countries (c. I500-I680), Leiden/Boston, Brill/Nijhoff, 2020. On consilia dealing with inter-polity disputes and diplomatic issues, see R.M. Greenwood, Law and War in Late Medieval Italy: the Jus Commune on War and its Application in Florence, c. IIso-I45o, PhD thesis, Centre for Medieval Studies, University of Toronto, 20II. I am presently working on a monograph on Baldus de Ubaldis (I327I400) in which also a number of such consilia are studied.

22 See K. Pennington, « Learned Law, Droit Savant, Gelehrtes Recht: The Tyranny of a Concept », Rivista internazionale di diritto comune, 5 , 1994, p. 197-209.

23 See P. Chaplais, English diplomatic practice in the Middle Ages, London and New York, Hambledon and London, 2003, p. 12-16, 24-26, 49-50, I02-103, I77-178 and I8I, and D.E. Queller, The Office of Ambassador (note 4), p. III-II2 and 197. 
themselves could meet, or the recipient of a mission had to trust the ambassador and have confidence that the latter's action would be endorsed by his principal on his return home. The letters of credence gave no such assurance, but envoys tasked with conducting negotiations were generally men whose dignity, political stature, and close association with their principal guaranteed the endorsement of their actions ; these men were usually referred to as credibiles personae, credibiles legati or probabiles viri ${ }^{25}$.

7. It was not until the twelfth century that the use of a new - formal - written document originated in Italian diplomacy, and quickly spread across Western Europe : this document was a procuration, or mandate (the two terms were synonymous in medieval legal practice and scholarship) ${ }^{26}$. Actually, the earliest known example of a clause de rato - i.e. a clause by which the sender promised to uphold whatever his agent did on his behalf - is found as early as Io63, in a letter by Alexander II which accompanied Peter Damiani in his mission to France : the pope declared that Damiani was sent « in his own place » to wield an authority second only to the pope's, and expressly stated that whatever decree Damiani adopted would be confirmed as if the pope himself had issued $\mathrm{it}^{27}$. In secular diplomacy procurations appeared some time later. Initially, somewhat hybrid documents were produced - letters of credence including a clause de rato. A famous example, studied by Donald Queller, dates from I2oI, when Geoffroi de Villehardouin and his colleagues carried letters from the Counts of Champagne, Flanders and Blois, on whose behalf they negotiated the transport of the Fourth Crusade army to the Levant with the Venetian government ${ }^{28}$. But soon the procuration became a separate document, addressed to the ambassador himself (not to the recipient of the mission, as was the letter of credence) and granting him the power to conclude negotiations on behalf of the principal. An early example is that of the procuration containing full powers given by Frederick Barbarossa to the bishop of Asti and two other persons to negotiate and conclude a peace treaty with the rebellious Lombards : « whatever you accept - wrote the Emperor -, we will accept it as well, and whatever you confirm by your promise or oath, we will hold it to be valid and put it into effect $\gg$. It was on the grounds of this procuration that the peace, later ratified by the Emperor at Constance, was concluded by Barbarossa's envoys at Piacenza, in April $1183^{29}$.

8. The procuration, therefore, differed from the letter of credence. Its most distinctive element, in the final instance, was the clause de rato. Canon lawyers soon started to consider this clause necessary in any procuration, as evidenced in the 1190 s by Bernardus Papiensis' Summa decretalium ${ }^{30}$. The Ordinary

24 See P. Chaplais, English diplomatic practice in the Middle Ages (note 23), p. 17, 47-48, 192, 199, and D.E. Queller, The Office of Ambassador (note 4), p. 122-123 and 125-126.

25 See P. Chaplais, English diplomatic practice in the Middle Ages (note 23), p. 56-59.

26 See G. Post, Studies in Medieval Legal Thought. Public Law and the State I100-I322, Princeton, New Jersey, Princeton University Press, 1964, p. I05-I06, and A. Padoa Schioppa, « Sul principio della rappresentanza diretta nel Diritto canonico classico $\gg$, in Proceedings of the Fourth International Congress of Medieval Canon Law (Toronto, 2I-25 August 1972), ed. S. Kuttner, Città del Vaticano, Biblioteca Apostolica Vaticana, 1976, p. I07-I3I : I2I. Before that period, procurationes were mostly used for legal representation in court: see H. Hofmann, Repräsentation. Studien zur Wort - und Begriffsgeschichte von der Antike bis ins 19. Jahrbundert, $4^{\text {th }}$ ed., Berlin, Duncker \& Humblot, 2003, p. IIO-II5, and D.E. Queller, The Office of Ambassador (note 4), p. I16, note 39.

27 The letter is published in Patrologia Latina, vol. I46, ed. J.-P. Migne, Parisiis, Apud Garnier fratres, editores et J.-P. Migne successores, I884, col. I295-I296 : « Huic itaque vicem nostram pleno jure commissimus, ut quidquid in illis partibus, Deo auxiliante, statuerit, in ratum teneatur et firmum ac si speciali nostri examinis fuerit sententia promulgatum $\gg$. See P. Blet, Histoire de la Représentation (note 7), p. 93, and R. Schmutz, « Medieval Papal Representatives » (note 9), p. 448.

28 See D.E. Queller, «L'évolution du rôle de l'Ambassadeur : les pleins pouvoirs et le traité de i2or entre les Croisés et les Vénitiens » (196I), in Id., Medieval diplomacy and the Fourth Crusade, London, Variorum Reprints, 1980, p. 479-50I.

29 See Die Urkunden Friedrichs I. II8I-IIgo, ed. H. Appelt (MGH Diplomata, t. X/4), Hannover, Hahnsche Buchhandlung, I990, n. 842, p. 54 : «Itaque verbum tractande pacis et concordie inter nos et Lonbardos eos, qui rebelles sunt imperio, sinceritati vestre proponendum et consumandum committimus plenam vobis nostre auctoritatis potestatem conferentes, ut, quecumque vos acceptaveritis, nos quoque acceptemus, et que promissione vel iuramento firmaveritis, nos rata habeamus et exequamur ». See P. Chaplais, English diplomatic practice in the Middle Ages (note 23), p. 6I-66, who also discusses other examples.

30 See Bernardus Papiensis, Summa decretalium (note 8), liber I, tit. 29 (De procuratoribus), $\$ 7$, p. 24: « Effectus procurationis est, ut ratum sit quod geritur cum procuratore, ac si cum domino gestum esset, ut infra eod. c. I (Gr. c. I I.38) . Similarly, see Tancredus, Ordo iudiciarius, Pillii, Tancredi, Gratiae Libri de iudiciorum ordine, ed. F.C. Bergmann, Gottingae, Apud Vandenhoeck et Ruprecht, I842 [reprint Aalen, Scientia Verlag, 1965], pars I, tit. 6 (De procuratore), $\$ 7$, p. I2I : «Effectus procuratoris est, ut ratum sit, quidquid cum eo agitur ». See also the passage by Goffredus de Trano quoted infra, note 33 . 
apparatus to the Liber extra, composed and repeatedly revised by Bernardus Parmensis between 1234 and I266, lists analytically the elements that a procuration should include. Two texts collected in the section de procuratoribus are of particular relevance. The first is a letter by which Gregory the Great, in November 602, refused to comply with the request of the bishop of Salona to invalidate the action carried out by two people who had acted in the bishop's name without his authorisation : the pope observed that the envoys dispatched to him with the bishop's request lacked a written mandate, and asked the bishop to send an « instructed person » carrying a procuration legally drawn up and authenticated with the signatures of the bishop and his witnesses ${ }^{31}$. The second text, a decretal by Gregory IX, stated that if a party to a litigation revoked his procurator's mandate after the litis contestatio without making the other party and the judge aware of the revocation, the judgement subsequently delivered, although it mentioned this procurator, was nonetheless valid ${ }^{32}$. A gloss to the first letter states that any mandate should include three elements, i.e. the name of the principal, the causa for which the procurator is appointed and the de rato clause $^{33}$. Further elements are added in a gloss to the second decretal, which mentions the names of the principal and the procurator, the causa for which the latter is appointed, the de rato clause and the judge before whom the case is brought, especially if he is a delegated judge ${ }^{34}$. Elsewhere Bernardus Parmensis expressed the need for a de rato clause in any mandate by saying that there was no difference between a mandatum and literas de ratoss.

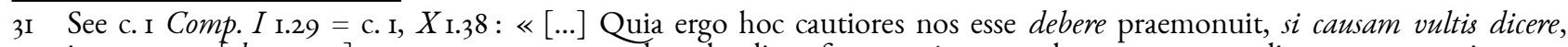
instructam [de cetero] personam cum mandato legaliter facto, tuis et presbyterorum seu diaconorum testiumque subscriptionibus roborato, gestisque ex more indicto transmitte, ut quicquid cum ea actum fuerit iure subsistat $\gg$ (the words in italics are in parte decisa and are only printed in Friedberg's edition of the Liber extra).

32 See c. I3, $X_{\text {I.38. }}$

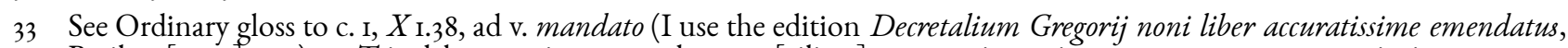
Basilee, [n. p.], I5II) : « Tria debet continere mandatum, $s$ [cilicet] nomen eius qui procuratorem eum constituit, et causam ad quam constituitur, et quod ratum habebit quod cum eo factum fuerit, ut ff. e.ti. si procuratorem [ Dig. 3.3.65] [...] $\gg$. In the 1582 Roman edition of the Corpus iuris canonici, a marginal note on col. 458 says that « haec glossula non est Bernardi, nec habetur in vetustis exemplaribus $\gg$. I have checked several manuscripts of the Biblioteca Apostolica Vaticana. In fact, this gloss is not found in either the ms Pal. lat. 634, $\mathrm{f}^{\circ}$ 53va (which preserves the first version of Bernardus' apparatus, I234I24I), the ms Vat. lat. 1383, fo 6rrb (which preserves its third version, I245-I253), or the following manuscripts (which all preserve its fourth version, I263) : Vat. lat. I38I, fo $65 \mathrm{ra}$; Vat. lat. I382, fo $72 \mathrm{ra}$; Vat. lat. I384, fo $68 \mathrm{v}^{\circ}$; Vat. lat. I385, fo $78 \mathrm{va}$; Vat. lat. I387, fo 63va ; Vat. lat. I388, fo 82va ; Vat. lat. I389, fo 8ova; Vat. lat. 1390, fo 7ora ; Vat. lat. I39I, fo 7ivb ; Borgh. 262, fo $77 \mathrm{vb}$; Pal. lat. 63I, fo $78 \mathrm{va}$; Pal. lat. 632, fo 6ovb; and Urb. lat. 159, fo $7 \mathrm{Ivb}$. On the other hand, the gloss is found in the following manuscripts, which also preserve the fourth version of the apparatus : Vat. lat. $1379, \mathrm{f}^{\circ}$ 69rb ; Vat. lat. I386, fo $6 \mathrm{Iva}$ (as a marginal additio); Borgh. 257, $\mathrm{f}^{\circ} 42 \mathrm{rb}$; and Pal. lat. 633, fo $59 \mathrm{va}$. It might therefore seem that this gloss was a later additio that, at some time, was incorporated into Bernardus' apparatus. However, as remarked by G. Post, Studies in Medieval Legal Thought (note 26), p. 51, note 134, this gloss is already found in Tancredus' Ordinary apparatus to Compilatio prima (c. I, Comp. I I.29) : see ms Vat. lat. 2509 (original version, before I2I5), fo I6vb, and Vat. lat. I377 (final version, c. 1220), fo $17 \mathrm{rb}$. Tancredus expressed the same idea with regard to the syndicus in his ordo iudiciarius, see Pillii, Tancredi, Gratiae Libri de iudiciorum ordine (note 30), pars I, tit. 7 (De syndico et actore), \$2, p. I25. On the other hand, the clause de rato is not mentioned among the constitutive elements of a mandatum by Goffredus de Trano, Summa super titulis Decretalium, Lugduni, Romanus Morin, I519 [reprint Aalen, Scientia Verlag, 1968 and 1992], liber I, tit. De procuratoribus, fo $64 \mathrm{va}$, n. 4 , who nevertheless on $\mathrm{f}^{\circ} 66 \mathrm{vb}$, n. 18 writes (just as Bernardus Papiensis and Tancredus, for whose opinions see supra, note 30) that « effectus procuratoris seu procurationis est ut ratum est [!] sit quod cum procuratore geritur ac si cum domino gestum esset » (this Summa was written in the years I24I-I243 according to M. Bertram, s.v. «Goffredo da Trani », in Dizionario biografico degli Italiani (note 19), vol. 57, 20or, available at http://www.treccani.it/enciclopedia/goffredo-da-trani (Dizionario-Biografico)/; the word « est » is not found in the version of the text that is preserved in the ms Paris, BnF, Latin I54II, fo $19 \mathrm{vb}$ ). The four stages of redaction of Bernardus Parmensis' Ordinary apparatus to the Liber extra have been determined by S. Kuttner and B. Smalley, « The "Glossa Ordinaria" to the Gregorian Decretals », The English Historical Review, 60, 1945, p. 97-105. Further information and bibliography can be found in the entry «Bernardus Parmensis », Bio-Bibliographical Guide to Medieval and Early Modern Jurists, available at http://amesfoundation.law.harvard.edu/BioBibCanonists/Report Biobib2.php? record id $=\mathrm{aO} 62$.

34 See Ordinary gloss to c. $13, X_{\mathrm{I} .38}$, ad v. mandato procuratoris : « De mandato procuratoris actoris dictum est s. e.c. $\mathrm{j}$ [c. I, $X_{\mathrm{I} .38}$ in mandato enim procuratorio debet contineri precipue nomen eius qui constituit procuratorem, et nomen procuratoris, et in qua causa et quod ratum habebit quod cum eo actum erit, sicut in literis de rato, et coram quibus iudicibus maxime si sunt delegati [...] ».

35 See Ordinary gloss to c. $8, X_{3.36}$, ad v. procuratione vel ratibabitione: « Vel dic quod non est differentia inter mandatum procuratorius et literas de rato $[. ..] \gg$. On this gloss, and its relation to a previous gloss by Johannes Teutonicus to the same decretal in the Compilatio quarta (c. 2, Comp. $I V$ 3.I3), see A. Padoa Schioppa, « Sul principio della rappresentanza diretta $\gg($ note 26$)$, p. I22, note 47 . 
9. In the fourteenth century, Bartolus de Sassoferrato (1313/I4-I357) distinguished a procuration from a letter of credence when he commented on the lex Lucius in the section de fideiussoribus et mandatoribus of the Digesta. This lex presented a private law case concerning a certain Lucius Titius, who had bound himself by letter as guarantor for a loan a third person had made to his brother. In his comment, Bartolus stated that it is one thing to ask someone to trust what an envoy says, or to recommend an envoy to him ; but quite another thing to grant the envoy the power to enter into a contract in the sender's name. And so, general formulas such as «trust the bearer of these letters in everything he tells you about me », « trust [him], who is fully informed of my intention » or « trust him fully in this matter » only ask the other party to believe what the bearer of the letters says, not to negotiate with him. In other words, they are mere letters of recommendation, which do not bind the sender to uphold the action carried out by their bearer, unless the particular situation requires otherwise (for example, if the bearer is the sender's factor or institutor in a certain business, because then the sender seems to be asking to trust his agent in relation to this specific business) or the sender explicitly assumes the risk of the action ${ }^{36}$. Bartolus' opinion was accepted by later jurists like Baldus de Ubaldis and Bartolomeus de Saliceto (d. I4II), and was explicitly applied to the ambassador in the two most important late-fifteenth-century legal writings on this office, namely the entry «Ambasiator » in Johannes Bertachinus' Repertorium iuris (I48I), and Gonzalo de Villadiego's Tractatus de legato (I485) ${ }^{37}$. Bertachinus referred to Bartolus' comment on lex Lucius after briefly stating that an «ambassador (ambasiator) » could not enter into any contract in his principal's name by virtue of mere credentials, and Villadiego reproduced a large portion of Bartolus' comment (with only very slight changes) in the third section of his treatise, which deals with nuntii ad negotia ${ }^{38}$. These sources are clear evidence of the transfer of notions and rules from private to public law, and of the former's contribution to the discussion of ambassadorial powers.

Io. Although today we are used to the notion of perfect, or direct, representation, which is grounded solely in an agreement between an agent and his principal, this general notion did not exist in the Middle Ages and was not elaborated until early modernity, within the framework of a general theory of contracts based on notions like the subject of law and the autonomy of the will ${ }^{39}$. For a long time, even the de rato clause was not explicitly interpreted as granting an agent the power to represent directly his principal ${ }^{\circ}$. In fact, medieval scholarship did not envisage a general theory of representation, instead endeavouring to offer solutions in a variety of situations in which Roman law allowed people to act for others despite the general interdiction expressed in the Digesta (or at least what medieval jurists considered to be a general

36 See Bartolus de Sassoferrato, In Secundam Digesti Novi Partem, Venetiis, [L.A. Giunta], I596, ad Dig. 46.I.24, fo 67va67vb, n. I : «Quid de literis, quae dicuntur in vulgari, literae credentiae ? Circa eas est sciendum. Nam quandoque sunt multum generales, ut "tali latori praesentium in his, quae vobis dixerit, dabitis plenam fidem", tunc vigore earum nil poterit agere talis lator in praeiudicium scribentis, quoniam istae literae sunt magis commendatoriae. Q[uandoque] $\mathrm{d}[$ icunt] "iste lator est fidelis persona, potestis de ipso confidere", \& sic non obligant scribentem [...]. Fallit si ex qualitate personae scribentis appareat aliud, ex quo generalitas illa certificaretur, ut si ille de quo scribebat, erat factor, seu institor scribentis in aliqua mercantia, quia tunc videtur dicere quod ei adhibeat fidem in negotio illius mercantiae. [...] Item fallit si dixit in epistula, " $\&$ adhibete ei plenam fidem super me, vel meo periculo", ut s. man. l. si vero, non remunerandi $\S$ si quis mandaverat, in fi[ne] [Dig. I7.I.I2.I3]. Quandoque istae literae sunt magis speciales, ut puta "tali latori praesentium de intentione nostra plenarie informato, dabitis plenam fidem". Et hic adverte, quia mandatur tamen, ut tali credatur id, quod ei refert, non autem mandatur, ut cum eo aliquis contractus celebretur, aliud enim est credere referenti, quia hoc nullam dispositionem continet, aliud est contrahere. Si ergo cum tali aliquis celebretur contractus, non obligat mandantem, quia excessit fines mandati, ut s. man. l. diligenter [Dig. I7.I.5] [...] ».

37 See Baldus de Ubaldis, In quartum et quintum Codicis libros commentaria, Venetiis, [Società dell'aquila che si rinnova], 1599 [reprint Goldbach, Keip Verlag, 2004], ad Cod. 4.26.13, fo 72rb-72va, n. I-5, and Bartolomeus de Saliceto, In tertium et quartum Codicis libros, Venetiis, Sub insigne Aquilae renovantis, I574, ad Cod. 4.26.13, fo $160 v b$.

38 See Johannes Bertachinus, Repertorium iuris. Pars prima, opera et labore Do. Ian. Thierry, Lugduni, Excudebat Bartholomaeus Fraenus, I552, s.v. « Ambasiator », fo $56 \mathrm{vb}$, and Gonzalo de Villadiego, Tractatus de Legato, in Tractatus Universi Iuris, t. XIII/2, Venetiis, Società dell'Aquila che si rinnova, 1584 , pars III, q. I, fo 28Iva, n. 28-3I. On Bertachini, see M. Caravale, s.v. « Bertachini, Giovanni », in Dizionario biografico degli italiani (note 19), vol. 9, 1967, available at http:// www.treccani.it/enciclopedia/giovanni-bertachini \%28Dizionario-Biografico\%29/. On Villadiego, see L. García Arias, «La doctrina diplomática expuesta por Gonzalo de Villadiego en su "Tractatus de Legato" », Cuadernos de historia diplomática, 3, 1956, p. 275-324.

39 On the renewal of contract law in the early modern period, see W. Decock, Theologians and Contract Law. The Moral Transformation of the Ius Commune (ca. I500-1650), Leiden/Boston, Martinus Nijhoff, 2013.

40 A. Padoa Schioppa, «Sul principio della rappresentanza diretta » (note 26) specifically deals with the problem of direct representation in canon law; on the de rato clause, see p. I2I-I23. 
interdiction - «alteri stipulari nemo potest », Dig. 45.I.38.17) ${ }^{41}$. Civil and canon lawyers soon began to ponder issues like representation in lawsuits, the acquisition of possession or property through an agent, marriage by proxy, or the legality of taking an oath on the soul of one's principal ${ }^{42}$. Within this debate, different types of agent were outlined, the most important of which were the nuntius and the procurator. Medieval jurists stressed the distinction between these two kinds of agent, considering the nuntius to be no more than the voice of his sender, whose words he repeated, and comparing him to a « magpie (pica) » and an « instrument (organum) ». In so doing, they implied that a nuntius had no autonomy or discretionary powers, but could only deliver a message or sign a contract which had already been agreed upon : everything a nuntius did was, in fact, automatically considered to have been done by his sender. In contrast, the procurator could negotiate and conclude an agreement : he was not simply held to be an instrument in the hands of his principal, but an agent provided with certain discretionary powers. As a result, the general view was that the act performed by a nuntius immediately produced legal effects in the principal's legal sphere, while the act performed by a procurator only produced legal effects in the principal's sphere after having been transferred to him (through a cessio actionis or a traditio) ${ }^{43}$. Other kinds of representative were the syndicus and the actor. According to Accursius (d. ante September I262), although an actor could also «sometimes » represent individuals, both were usually appointed by a community: the actor on an ad hoc basis, the syndicus for all matters. While the Digesta equated the syndicus and the defensor civitatis in some passages ${ }^{44}$. Accursius used defensor as a general term for any agent of a universitas, and considered actor and syndicus to be kinds of defensorest5. Given that a section de syndico (just as a section de procuratoribus) had been included in the canon law collections since the Breviarium extravagantium, canon lawyers extensively wrote on the office of syndic ${ }^{46}$. They also provided a decisive contribution to the conceptualisation of collegia and other bodies composed of a plurality of human beings as legal persons, using to this end the concept of persona ficta or repraesentata ${ }^{47}$. A syndicus

4I On representation in Roman law, see M. Miceli, Studi sulla "rappresentanza" nel diritto romano, vol. I, Milan, Giuffrè, 2008; G. Coppola Bisazza, Dallo iussum domini alla contemplatio domini. Contributo allo studio della storia della rappresentanza (Corso di diritto romano), Milan, Giuffrè, 2008 ; and J.E. Rodríguez Diez, Potestas alienandi. Transfer of ownership by a non-owner from Roman law to the DCFR, Oisterwijk, WLP, 2016. A rich collection of studies on representation from Antiquity to Modernity is Agire per altri. La rappresentanza negoziale, processuale, amministrativa nella prospettiva storica, ed. A. Padoa Schioppa, Naples, Jovene, 20 o.

42 On late medieval scholarship on private law agency and diplomatic representation, see R. Fränkel, « Die Grundsätze der Stellvertretung bei den Scholastikern », Zeitschrift für vergleichende Rechtswissenschaft, 27, 1912, p. 289-391; H.F.W.D. Fischer, « Les doctrines des romanistes du Moyen Âge sur l'acquisition de la possession et de la propriété par l'intermédiaire d'un mandataire », in Symbolae ad jus et bistoriam antiquitatis pertinentes Julio Christiano Van Oven dedicatae (Symbolae Van Oven), ed. M. David, B.A. van Goningen and E.M. Meijers, Leiden, Brill, 1946, p. 36I-378; P. Legendre, « Du droit privé au droit public. Nouvelles observations sur le mandat chez le canonistes classiques » (1970), in Id., Écrits juridiques du Moyen Âge occidental, London, Variorum Reprints, 1988 ; A. Padoa Schioppa, «Sul principio della rappresentanza diretta » (note 26); L. Mayali, «Procureurs et représentation en droit canonique médiéval », Mélanges de l'École française de Rome. Moyen Âge, II4 (I), 2002, p. 4I-57; H. Hofmann, Repräsentation (note 26); G.P. Massetto, «La rappresentanza negoziale nel diritto comune classico », in Agire per altri (note 4I), p. 393-494; B. Pasciuta, «La rappresentanza processuale nell'età del diritto comune classico », ibid., p. 495-534; and D. Fedele, Naissance de la diplomatie moderne (note 5), p. 205-224.

43 See D.E. Queller, «Thirteenth-Century Diplomatic Envoys: Nuncii and Procuratores » (1960), in Id., Medieval Diplomacy (note 28); and Id., The Office of Ambassador (note 4), p. 3-59, who provides many references to both legal practice and scholarship.

44 See Dig. 50.4.I.2 and Dig. 50.4.I8.I3, which reads : « Defensores quoque, quos graeci syndicos appellant, et qui ad certam causam agendam vel defendendam eliguntur, laborem personalis muneris adgrediuntur $\gg$; the Ordinary gloss ad v. eliguntur identifies those who are appointed ad certam causam with actores, referring to Dig. 3.4.I.I (I use the edition Corpus iuris civilis, 5 vol., Lyons, Hugues de la Porte, I558-1560).

45 See the Ordinary gloss ad Dig. 3.4.I.I, ad v. syndicum. On the relation of this gloss to pre-Accursian glosses to the same lex, see V. Crescenzi, « Le origini del Sindicus-procurator a Siena (secc. XII-XIII) », Archivio storico italiano, 478, 1973, p. 351$438: 375-385$.

46 See Bernardus Papiensis, Summa decretalium (note 8), liber I, tit. 29 a (De syndico), p. 25 (« Tractavimus de procuratore, qui agit causam alienam; nunc tractemus de syndico, qui agit causam universitatis »); Tancredus, Ordo iudiciarius, in Pillii, Tancredi, Gratiae Libri de iudiciorum ordine (note 30), pars I, tit. De syndico et actore, p. I23-126; Goffredus de Trano, Summa (note 33), liber I, tit. De syndico, fo 67ra-67va; Innocent IV, In quinque libros Decretalium apparatus,

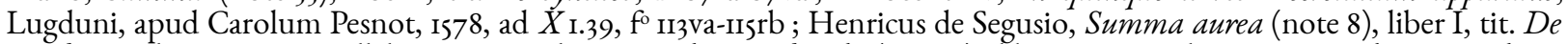
Syndico, col.397-402; Guillelmus Durandus, Speculum iudiciale (note 8), liber I, particula III, tit. De bis, qui alieno nomine in Iudicio interveniunt, p. 201a-202a ; and ibid., tit. De syndico, p. 233b-238a. 
who carried a procuration, therefore, had procuratorial powers and was held to represent the whole community - understood as a corporate body (universitas) - which had elected him ${ }^{48}$.

II. That said, it is worth pointing out that the abovementioned distinction of different kinds of agents was nuanced in legal scholarship. Bartolus de Sassoferrato, for example, argued that, in some situations, the procurator could act as a representative who produced immediate legal effects in his principal's legal sphere. What were these situations? Bartolus said that this happened when the procurator accomplished some « natural acts , or acts related to rights or obligations that were « so personal, that they cannot be transferred from the procurator to the dominus ». For instance, when a procurator was appointed to take an oath on his principal's soul, or to take possession of a good, or to marry a woman on the principal's behalf, he did not need to transfer the rights and obligations deriving from such acts to the principal, since they were immediately produced in the latter's legal sphere. In such situations, Bartolus wrote, « the procurator directly represents the person of the dominus, just as a nuntius does $\gg 49$. This is a key passage, in which the phrase «personam (alicuius) repraesentare directo » is used in a technical sense to define direct representation ${ }^{50}$. The originality of this affirmation deserves special emphasis. Admittedly, the concept of « representation » had already been used by Pierre de Belleperche (c. 1247?-1308) in relation to the action of a servus, which - according to Roman law - directly bound the dominus, but Bartolus' remark was far more general, and also applied to the action carried out by a free man ${ }^{\text {II }}$. Moreover, as convincingly argued by Hasso Hofmann, the aforementioned concept of persona repraesentata - the first occurrences of which Robert Feenstra traced back to Jacques de Revigny (c. 1230/40-1296), and possibly his master Jean de Monchy (d. c. 1266) - did not refer to the exercise of vicarial representation (representation as Stellvertretung), but was intended to define, through a constructive use of fiction, corporations as abstract legal entities (representation as Nachbildung)s. ${ }^{s^{2}}$. However, we can see that, even in Bartolus, direct representation was not a general institution depending solely on the will of the parties : it was considered to be an exceptional case, and depended on the specific quality of the acts involved, which produced rights and obligations that could not be transferred to another person. This, at least, was the situation under the ius commune: from the late thirteenth century on, Italian statutes and customs began recognising a much broader applicability of direct representation, which undoubtedly facilitated commerce and economic exchanges ${ }^{33}$.

47 See R. Feenstra, «L'histoire des fondations. À propos de quelques études récentes », Tijdschrift voor Rechtsgeschiedenis, 24 (4), 1956, p. 38I-448 (the version reprinted in Id., Le droit savant au Moyen Age et sa vulgarisation, London, Variorum Reprints, 1986 includes some additions at the end of the volume, but omits the p. 383-407 of the original article); P. Michaud-Quantin, Universitas : expressions du mouvement communautaire dans le Moyen-Age latin, Paris, Vrin, 1970 ; J. Canning, The Political Thought of Baldus de Ubaldis, Cambridge et al., Cambridge University Press, 1987, p. I85-208; I. Birocchi, s.v. «Persona giuridica nel diritto medioevale e moderno $»$, in Digesto delle discipline privatistiche, $4^{\text {th }}$ ed., sez. Civile, vol. XIII, Turin, UTET, 1995, p. 407-420; R. Feenstra, « Foundations in Continental Law since the $12^{\text {th }}$ Century: The Legal Person Concept and Trust-like Devices », in Itinera Fiduciae. Trust and Treuband in Historical Perspective, ed. R. Helmholz and R. Zimmermann, Berlin, Duncker \& Humblot, 1998, p. 305-326; and Y. Thomas, « L'extrême et l'ordinaire. Remarques sur le cas médiéval de la communauté disparue » (2005), in Id., Les opérations du droit, ed. M.-A. Hermitte and P. Napoli, Paris, EHESS/Gallimard/Seuil, 20II, p. 206-237, with further references. For a critical view, see S. Reynolds, «The history of the idea of incorporation or legal personality : a case of fallacious teleology », in Ead., Ideas and Solidarities of the Medieval Laity. England and Western Europe, Aldershot, Variorum, 1995 .

48 See G. Post, Studies in Medieval Legal Thought (note 26), p. 27-6o.

49 See Bartolus de Sassoferrato, In Primam Digesti Novi Partem, Venetiis, [L.A. Giunta], I596, ad Dig. 39.2.13.13, fo 28rb, n. 3 : «In his, quae adeo sunt personalia, quod ex persona procuratoris non possunt transire in dominum, procurator repraesentat personam domini directo, sicut nuncius $\gg$.

so See H. Hofmann, Repräsentation (note 26), p. 159-170.

5I See Pierre de Belleperche, Lectura Institutionum, apud haeredes Simonis Vincentii, Lugduni, I536 [reprint Bologna, Forni, 1972], ad Inst. I.8, p. 200, n. IO: «Interpretatione iuris eadem persona est servus cum domino [...] : tunc [servus] repraesentat personam domini $\gg$.

52 See H. Hofmann, Repräsentation (note 26), p. I32-I48. On legal fiction in the Middle Ages, see F. Todescan, Diritto $e$ realtà : storia e teoria della fictio iuris, Padua, Cedam, 1979, p. 8I-210, and Y. Thomas, « Fictio legis. L'empire de la fiction romaine et ses limites médiévales $\gg$ (1995), in Id., Les opérations du droit (note 47), p. 133-186.

53 See R. Fränkel, « Die Grundsätze » (note 42), p. 296-298; and G.P. Massetto, « La rappresentanza negoziale » (note 42), p. 394-399 and 456-460 for numerous examples. 
I2. Not only was the distinction between different kind of agents nuanced in legal scholarship, but it was also scarcely observed in actual practice. In fact, in late medieval diplomatic practice, the terms nuntius, procurator and syndicus were often used interchangeably, or even together, or in conjunction with other titles like actor, factor, oeconomus, orator, commissarius, negotiorum gestor or ambasiator. The quality and powers of each envoy, therefore, always had to be inferred not from his title, but from the documents he carried with him and the precise powers that these granted him. In some cases, legal scholars, especially in the fields of canon and procedural law, recognised and partly accepted this redundancy, stating that, in the interpretation of the documents borne by the envoy, the principal's intention had to prevail over the literal words ${ }^{54}$. In a famous passage of his Summa, Henricus de Segusio declared that « we do not give great force to names, for whether [an envoy] is called procurator, or syndic, or economus, or ass, or even if no name is expressed, it doesn't matter as long as the mind of the person constituting him is clear »ss. In other cases, however, legal scholars continued to use each term with due precision, as demonstrated by the aforementioned late-fifteenth-century works on the ambassador written by Johannes Bertachinus and, above all, Gonzalo de Villadiego ${ }^{56}$.

I3. Roman law distinguished between two kinds of mandate, mandatum generale and mandatum speciale. A special procurator was appointed for a specific task, while a general procurator was appointed for the entirety of his principal's business, either for a limited period of time or in perpetuity ${ }^{57}$. The degree of precision required for a mandate to be deemed «special » could vary in jurists' opinions. In the fourteenth century, Guillaume de Cun (d. 1336) argued that a special mandate had to indicate both the exact situation in which the procurator was to accomplish his act, and the person with whom he had to deal ; Baldus de Ubaldis criticised this view, and stated that indicating the act to be performed in general terms sufficed ${ }^{8}$. On the other hand, a general mandate conferred rather limited powers and was of very little use in diplomatic practices; however, it was considered to produce the same effects as a special

54 See Gratia Aretinus, Summa de iudiciario ordine, in Pillii, Tancredi, Gratiae Libri de iudiciorum ordine (note 30), pars I, tit. De procuratoribus et syndicis, $\$ 2$, p. 348 ; and Ædigius de Fuscarariis, Ordo iudiciarius, in Quellen zur Geschichte des römisch-kanonischen Processes im Mittelalter, ed. L. Wahrmund, vol. III, Verlag der Wagner'schen K.K. UniversitätsBuchhandlung, Innsbruck 1916, cap. XIII (Qualiter procurator rei constitui debeat, ut relevetur a satisdatione), p. 23-24. On these texts, see B. Pasciuta, «La rappresentanza » (note 42), p. 522-525. On the distinction between procurator and syndicus in particular, see G. Post, Studies in Medieval Legal Thought (note 26), p. 41-42.

55 See Henricus de Segusio, Summa (note 8), liber I, tit. De Procuratoribus, col. 385, n. I : « Sed secundum iura nostra, planum est : quia non facimus vim in nominibus, nam sive dicatur procurator, sive syndicus, sive oeconomus, sive asinum, sive etiam nullum nomen exprimatur, nihil ob[stat] dummodo de mente constituentis liquesat », transl. D.E. Queller, The Office of Ambassador (note 4), p. 34.

56 See D.E. Queller, The Office of Ambassador (note 4), p. 14-25, 34, 42-52 and 58; L. Mayali, « Procureurs et représentation » (note 42), p. 46-47; and D. Fedele, Naissance de la diplomatie moderne (note 5), p. 229-23I.

57 See Dig. 3.3.I.I and Dig. 3.3.3-4.

58 See Baldus de Ubaldis, In primum, secundum et tertium libros Codicis Commentaria, Venetiis, [Società dell'aquila che si rinnova], I599 [reprint Goldbach, Keip Verlag, 2004], ad Cod.2.48.I, fo I62rb, n. 2: « Quaero [...] quod dicatur mandatum speciale? Dicit Guil[lelmus] de Cun[eo] in l. sed \& si quis, § quaesitum, ff. si quis cau. [Dig. 2.II.4.4] quando fit mentio causae \& personae, ut facio te procuratorem ad petendam restitutionem in integrum in tali causa contra talem. Istud est speciale mandatum, secundum Guil[lelmum]. Tu dic, quod non oportet quod fiat mentio certae \& limitatae causae \& personae, sed sufficit quod dicatur, facio te procuratorem ad petendum restitutionem in integrum. Et idem in omnibus, quae requiruntur speciale mandatum, ut sufficiat exprimere qualitatem actus, sicut sufficit constituere procuratorem ad opponendum crimina \& defectus, licet aliter non specificetur, ut in c. 2 de procur. in clem. [c. 2 , Clem. I.Io]. Non obstat dictum Guliel[mi] quia illud non esset mandatum speciale, sed singulare, seu specialissimum, quod lex non requirit. Item facit, quod no[tatur] in c. praesentium, de testib. lib. 6 [c. 2, VI 2.IO] ». See Guillaume de Cun ad Dig. 2.II.4.4, ms Oxford, Bodleian Library, Canon. misc. 472, fo $23 \mathrm{rb}$; ms Vienna, Österreichische Nationalbibliothek, Cod. 2257, fo 85va; and ms Lucca, Biblioteca Capitolare Feliniana, 373, fo $24 \mathrm{va}$.

59 See D.E. Queller, The Office of Ambassador (note 4), p. 35-36. On the limitations imposed on general procurators, see Dig. 3.3.63; Rogerius, Summa Codicis [recte Summa Tubingensis], in Scripta anecdota antiquissimorum glossatorum, vol. I, ed. I.B. Palmerio, editio altera emendata, Bononiae, ex aedibus Angeli Gandolphi, typis Societatis Azzoguidianae, I9I3, ad Cod. 2.8, p. $72 \mathrm{a}$, n. Io ; c. $28, X_{\mathrm{I} .3}$ (with Ordinary gloss ad v. sine speciali mandato); c. 9, $X_{\mathrm{I} .43}$; Ordinary gloss ad Cod.2.I3.IO, ad v.plenam; Magister Arnulphus, Summa minorum, in Quellen zur Geschichte des römisch-kanonischen Processes im Mittelalter, ed. L. Wahrmund, vol. I/2, Innsbruck, Verlag der Wagner'schen Universitäts-Buchhandlung, I905, cap. 5I (Forma procurationis), p. 54; Guillelmus de Drogheda, Summa aurea, in Quellen zur Geschichte des römischkanonischen Processes im Mittelalter, ed. L. Wahrmund, vol. II/2, Innsbruck, Verlag der Wagner'schen K.K. UniversitätsBuchhandlung, 1914, cap. Ios (De procuratoris delicto, an noceat domino), p. IOo; Guillelmus Durandus, Speculum indiciale (note 8), liber I, particula III, tit. De procuratore, p. 205b-206a, n. 4-5; c. 4, VI I.I9. 
mandate if a particular clause was added to it, granting the procurator plena potestas or libera administratio ${ }^{60}$. Like Cynus de Pistorio (c. 1270-1336), Baldus refers to the opinion of Jacobus de Arena (d. ante (302), according to which syndics appointed by universitates like cities, castra and villae held a publicum officium, and therefore did not need a special mandate to perform acts which normally required such a mandate; syndics appointed by collegia without public status, by contrast, did not held a publicum officium and so needed a special mandate to perform those acts ${ }^{61}$. Commenting on Cod. 2.4.I2, which referred to a compromise (transactio) made by the administrators of a city, both Bartolus and Baldus observed that, since compromises required a special mandate, the mandates granted to city administrators had to be understood to include implicitly libera administratio ${ }^{62}$. However, Baldus does not seem to have fully adopted Arena's view, as revealed by his comment on a clause of the Peace of Constance which required that the Lombard cities - except for those in which a bishop held comital office - send a nuntius to the emperor every five years, to request the investiture of new consuls. After reproducing a previous gloss by Odofredus clarifying that, in Italy, such nuntii were called syndici, Baldus here mentioned Jacobus de Arena's opinion, but then, drawing on Johannes Andreae, concluded that it was « safer » to say that, when they were required to accomplish acts requiring a special mandate, syndics had to bear either such a mandate, or a general one cum libera ${ }^{63}$.

I4. The impact of the principles and rules of private law agency on diplomatic representation and public international law is particularly evident in the juristic discussion about ratification. In medieval legal scholarship, ratibabitio or ratificatio was the act whereby a dominus could accept, with retroactive effect, an act performed by a false procurator - that is a procurator acting without procuration : according to the principle «ratibabitio mandato comparatur », after the ratibabitio a legal act performed by an unauthorised agent had the same effect as if it had been performed by an authorised agent ${ }^{64}$. But what about an act performed by an ambassador within the boundaries of his mandate ? Did it immediately bind his principal ? Or did the principal have to confirm it in some way ? In his study on the office of ambassador in the Middle Ages, Donald Queller demonstrated that representation in late medieval diplomatic practice could be either direct or indirect. According to Queller, ratification was not always necessary in strictly legal terms to make a treaty binding upon the principal, although it was nonetheless sometimes performed to give more publicity or solemnity to the outcome of negotiations ${ }^{65}$. In particular,

60 See G. Post, Studies in Medieval Legal Thought (note 26), p. 93-102.

6I See Jacobus de Arena, Commentarii in universum Ius civile, Ludguni, Impensis honesti viri Hugonis a Porta, I54I, ad Cod.2.48.I, fo IIra, n. 4 : «Et syndici universitatum qui gerunt publica officia possunt petere restitutionem, licet non habeant speciale mandatum. Pro hoc s. de offic. eius l. j [Cod. I.5o.I]. Sed syndicus monasterij qui non sit de gremio vel etiam si sit, non potest sine speciali mandato ». This opinion is cited by Cynus de Pistorio, Lectura super Codice, Francofurti ad Moenum, Impensis Sigismundi Feyerabendt, I578 [reprint Rome, Il Cigno Galileo Galilei, I998], ad Cod. 2.48.I, fo Iogvb, n. 4 ; as for Baldus de Ubaldis, see the next footnotes.

62 See Bartolus de Sassoferrato, In Primam Codicis Partem, Venetiis, [L.A. Giunta], I596, ad Cod.2.4.I2, fo 52 va, n. 4, and Baldus de Ubaldis, In primum, secundum et tertium libros Codicis Commentaria (note 58), ad Cod. 2.4.I2, fo II9va, n. 2.

63 See Baldus de Ubaldis, Lectura super usibus feudorum, Rome, In domo dominorum Anthonii et Raphaelis de Vulterris, [c. I474], ad PC, cap. 8 (In civitate illa), ad v. mittit [recte mittat], fo $154 \mathrm{va}$, after quoting Odofredus : « Et si plures sunt creati sindici ab universitate, gerunt publicam personam, videtur quod habeant mandatum insolidum, ar[gumento] ff. de admi. tu. l. decreto [Dig. 26.7.24], etiam in his que requiruntur speciale mandatum, ut ff. de iure iuran. l. iusiurandum, et ad pecunias $₫$ defensor [Dig. I2.2.34.I], et per Iaco[bum] de Are[na] C. etiam per procuratorem causam in inte. resti. agi pos. 1. i [ $\mathrm{Cod}$. 2.48.I]. Sed tutius est dicere quod in requirentibus speciale mandatum debeat speciale mandatum habere, vel generale cum libera, ut no[tatur] in c. praesentium, de testi. li. vi [c. 2, VI 2.Io] in Novella ». See Johannes Andreae, In Sextum Decretalium Librum Commentaria (quae Novellas appellavit) Acutissima, Venetiis, Apud Franciscum Franciscium, Senensem, 158I [reprint Turin, Bottega d'Erasmo, 1966], ad c. 2, VI 2.I0, fo 72rb, n. 6: « Dicit Arch[idiaconus] quod sindicus sine speciali mandato iurandi non iurat, sicut nec procur[ator] privatae personae, de iur. cal. c. fi. [c. 3, VI 2.4]. \& est ratio, quia non habet generalem administrationem ». Guido de Baisio did not refer to syndici in his comment on c. 3, VI 2.4 (nor did he refer to them in his comments on the other decretals included in this section) : see Archidiaconus super sexto Decretalium, Lugduni, Apud haeredes Iacobi Giuntae, I547, fo 59 rb-59vb.

64 See Dig. 46.8.I2.I : «Rem haberi ratam hoc est comprobare adgnoscereque quod actum est a falso procuratore ». The Ordinary gloss ad v. procuratore clarified : «In falso exigitur ratihabitio : in vero non. Nam cogimur habere ratum : ut s. de procura. 1. non solum circa prin. [Dig.3.3.39.I] ».

65 See D.E. Queller, The Office of Ambassador (note 4), p. 209-222; on p. 213, Queller argues that « the total number of subsequent ratifications found among the documents is relatively small compared to the total number of covenants negotiated by plenipotentiaries $\gg$. See also P. Chaplais, English diplomatic practice in the Middle Ages (note 23), p. 60-6I and $7 \mathrm{I}$. 
it was not necessary when an ambassador had been granted full powers (plena potestas) to conclude an agreement. This thesis seems to have been confirmed by Victor Crescenzi's research on late-thirteenthcentury Siena, where two kinds of agent could be dispatched : on the one hand, « ambaxatores et sindici » were empowered to negotiate and enter into agreements that were directly binding on the city; on the other hand, simple « ambaxatores » could either present their commune's proposal and conclude an agreement if this were fully accepted (but had no power of negotiation), or negotiate a deal (although they were powerless to conclude it ${ }^{66}$. When it was performed, the ratification of treaties normally entailed the taking of an oath, either by the political leaders themselves or by duly entrusted envoys - which brought the enforcement of these treaties under the jurisdiction of ecclesiastical courts ${ }^{67}$. In their discussion about the extent to which public officials were entitled to represent parties in concluding agreements, late medieval jurists largely focused on the function performed by public notaries in the conclusion of contracts between private individuals ${ }^{68}$; other kinds of representative, however, were mentioned too although much less frequently ${ }^{69}$. Angelus de Ubaldis (1327/28-1407), for example, wrote that « those who fulfil a public office [...] can form the words of the payment directly in the person of the principal $\gg$, with the result that «any universitas is entitled to the actio [arising] from a contract [concluded by] his administrator without cessio $\gg^{70}$. In one of his consilia, dealing with a provision in the Florentine statutes about the contract concluded by a public notary (notarius) on behalf of a third person, Angelus noted that in some cases the ius commune admitted the possibility of producing legal effects in the principal's legal sphere immediately, that is without having to transfer these effects to him (« sine cessione »). Such cases, according to him, included the acts accomplished by a syndicus and an actor universitatis : these titles were, in fact, often attributed to ambassadors in medieval diplomatic practice and theory ${ }^{71}$.

\section{The influence of the late medieval notion of diplomatic representation on early modern scholarship on international law}

I5. Later sources give more explicit instances of the immediate validity of an act performed by ambassadors provided with full powers being accepted in legal doctrine, even though these sources also warn us that, in

66 See V. Crescenzi, « Le origini del Sindicus-procurator (note 45), p. 408-427.

67 See R. Lesaffer, « Peace Treaties from Lodi to Westphalia », in Peace Treaties and International Law in European History (note 4), p. 22-24, and Id., « Peace Treaties and the Formation of International Law », in The Oxford Handbook of the History of International Law, ed. B. Fassbender and A. Peters, Oxford, Oxford University Press, 2oI2, p. 74. However, as pointed out by O. Condorelli, «I foedera pacis e il principio pacta sunt servanda. Note di ricerca nel pensiero dei giuristi dei secoli XII-XV », Zeitschrift der Savigny-Stiftung für Recbtsgeschichte : Kanonistische Abteilung, I05, 2019, p. 80-82, canon lawyers considered the breach of any pactum nudum to be a mortal sin, regardless of whether or not it had been sanctioned by oath; this entitled the Church to judge the violation of pacta in general.

68 See G.P. Massetto, « La rappresentanza negoziale » (note 42), p. 403, 406 and 416-436.

69 See Baldus de Ubaldis, In primam Digesti Veteris partem Commentaria (note 8), ad Dig. 22.2.II, Ex lectura antiqua, f. I7ova, n. I : « Ex stipu[latione] officialis quaeritur Reipublicae ipso iure ».

70 See Angelus de Ubaldis, In I. atque II. Digesti Veteris Partem Commentaria, Venetiis, [L.A. Giunta], I580, ad Dig. 13.5.5.9, fo $232 \mathrm{rb}:$ : [...] his, qui publicum gerunt officium [...] possunt concipere verba solutionis directa in personam domini sui, dicendo, constituis te mihi soluturum domino meo. In tex[to] ibi, municipium. No[ta] quod cuilibet universitati ex contractu sui administratoris competit actio sine cessione ».

7I See Angelus de Ubaldis, Consilia, Francofurti, Typis Andreae Wecheli, sumptibus Sig. Feyrabend, 1575, consilium 73, fo $48 \mathrm{ra}$ : «In statuto Florentino cavetur, quod ex stipulatione notarij quaeratur ius, \& actio solum illi, cuius nomine stipulatus fuerit : \& absque alia cessione. Contingit, quod Florentinus notarius in territorio Florentinorum stipulatus est pro Perusino absente, a quo nullum mandatum stipulandi habebat. Quaeritur, an ex tali stipulatione actio sine cessione quaeratur ? \&c. Quod dicta actio \& ius sine cessione quaeratur, facit : quia dicta provisio statutaria per modum beneficij \& gratiae emanavit. Providet enim istis, quorum nomine stipulatio recipitur, ut eisdem sine cessione quaeratur : sicut providet ius commune in quibusdam casibus, in quibus alteri per alterum quaeritur utilis sine cessione, cum tamen stipulatur tutor aut notarius, rem pupilli salvam fore, aut aliquod aliud ad officium suum spectans, aut syndicus, vel actor universitatis, ut patet ex coniunctione ff. de consti. pecu. l. eum, qui $\S$ si actori [Dig. 13.5.5.9], ff. de adop. l. non aliter [Dig. 1.7.I8] \& 1. his verbis [Dig. 1.7.19] ». 
practice, ratification was often requested ${ }^{72}$. Although it is not possible, within the limits of the present article, to carry out a close analysis of the issue of diplomatic representation in early modern scholarship on international law, some examples will illustrate the persistence of the late medieval notion and approach in the discussion of the issue right up until the late eighteenth century, thereby allowing us to appreciate the importance of the contribution made by the ius commune to the early modern discussion of the status of the ambassador. A first example is provided by Pope Pius II's Commentaries, written in the years $1462 / 63$ : in one passage, Pius II talks about the Florentine citizens who, when reminded, in early I460, of the promise, made in Mantua by their ambassadors the year before, that Florence would contribute to the Crusade, answered that the ambassadors

had made the pledge in the name of the city, acting on [a mandate] (mandatum) from the priors and certain richiest $i$; this was normal procedure, but the pledge would not be valid until it was ratified (ratum babeatur) by the Great Council of the City. Only rarely did this body refuse to ratify what ambassadors with such a [mandate] (mandatum) had promised, but in this matter, which was of the gravest importance, there was not the slightest chance that the people would give their consent. [...] The pope was astonished that the Florentines could be so shameless. He inveighed at length against the injustice (iniustitiam) of those who lied and deceived in matters concerning the defence of the faith. To give ambassadors a mandate that had no authority (invalida... mandata) was a disgrace; it was even worse to exploit it to their own advantage [...]. But the pope was wasting his time. He decided to take what he could get. The state [i.e. Florence] was acting like a haggler (not to say a whore) and he dispensed with further negotiations ${ }^{73}$.

This case was cited by Alberico Gentili in his De iure belli (1598), in the chapter of book III concerning the law of agreements, to argue that a prince was always bound to observe a treaty concluded by his ambassador within the limits of his procuration, and had no right to invoke his discretionary power of ratification. Commenting on the case of the Florentine ambassadors, he asked : « How will you be able to rely on a mandate if you accept this way of thinking ? Or shall a thing so essential in human intercourse as the employment of procurators be abolished ? Against those Florentines, Pius II declared that it was shameful to send invalid mandates, and still more so to make use of them $\gg^{74}$.

I6. In the same chapter, Gentili mentioned another case, which became quite famous in early modern legal scholarship. According to Francesco Guicciardini's History of Italy, in 1503, during the war between France and Spain in the Kingdom of Naples, the Habsburg archduke Philip obtained from his parents in law King Ferdinand II of Aragon (Ferdinand the Catholic) and Queen Isabella I of Castile - full powers («ampia facoltà e libero mandato ») to conclude a peace with Louis XII. The peace was actually reached, and made public in Blois on II April, when both the French king and the archduke (as procurator of Ferdinand and Isabella) took an oath 75 . Louis XII immediately started to execute the peace, despatching someone to ask Ferdinand and Isabella to ratify $\mathrm{it}^{76}$; the latter, however, ignored the request for several months, until they expressly declared that they were not going to comply with it because, although Philip had received full powers («mandato [...] libero $e$ amplissimo »), his instructions were limited («istruzioni $[\ldots]$ limitate $»)$ and he should therefore have obeyed them ${ }^{77}$. Philip firmly denied having exceeded either his mandate or his instructions, and Louis XII - extremely annoyed about what had

72 On the early modern practice of ratification, see R. Lesaffer, « Peace treaties from Lodi to Westphalia » (note 67), p. 22-29.

73 See E.S. Piccolomini, I commentarii, ed. L. Totaro, $2^{\text {nd }}$ ed., Milan, Adelphi, 2004, IV.7, p. 66o-662, transl. Pius II, Commentaries, vol. II (books III-IV), ed. M. Meserve and M. Simonetta, Cambridge, Massachusetts and London, England, Harvard University Press, 2007, p. 221, slightly modified.

74 See A. Gentilis, De iure belli libri III, Hanoviae, Excudebat Guilielmus Antonius, I598, III.I4, p. 594-595 (« Eccui poteris mandato credere, si ratio ista recipitur ? Aut res adeo necessaria vitae huminum, ut est usus procuratorum, de vita tolletur ? Contra hos Florentinos Pius Secundus, turpe, mittere mandata invalida ; \& turpius, eis uti. Verissime. Etsi nihil profecit papa »), transl. De iure belli libri tres, translated by J.C. Rolfe, Oxford/London, At the Clarendon Press/Humphrey Milford, 1933, p. 363, modified.

75 See F. Guicciardini, Storia d'Italia, ed. E. Mazzali, Milan, Garzanti, 2006, V.I5, p. 573-574. Guicciardini wrote his History of Italy between 1535 and 1540 . On the Italian wars, see the synthesis by J.-L. Fournel and J.-C. Zancarini, Les guerres d'Italie. Des batailles pour l'Europe (I494-I559), Paris, Gallimard, 2003.

76 See F. Guicciardini, Storia d'Italia, V.I5, p. 574 (« Ma avendo subito il re e Filippo mandato nel regno di Napoli a intimare la pace fatta, e a comandare a' capitani che insino a tanto venisse la ratificazione de' re di Spagna, possedendo come possedevano, s'astenessino dalle offese $[. ..] \gg$ ).

77 See ibid., VI.I, p. 586-587. 
happened - expelled the two ambassadors who had been sent to him by the Spanish monarchs ${ }^{7}$. Discussed by Jean Bodin in Les six livres de la République ${ }^{79}$, this case was referred to by both Gentili and Hugo Grotius. The two jurists expressed similar opinions : the former commented that Ferdinand and Isabella's behaviour was « unbecoming for a prince, who should say: "I have spoken once and for all. What I have written, I have written. One pen, one tongue [...]”. But these Catholics have two pens, and two tongues $\gg^{80}$; as for the latter, he explicitly gave priority to the mandate over secret instructions, saying that when a treaty is concluded by an agent « whoever has appointed [him] is bound, even if the agent, while yet within the limits of his public function, has acted contrary to secret instructions $\gg^{8 \mathrm{I}}$.

17. In the second half of the seventeenth century, this doctrine was reaffirmed both by Samuel von Pufendorf, the holder of the first chair in the law of nature and of nations (established in Heidelberg in 1672) ${ }^{8_{2}}$, and by the Dutch ambassador Abraham de Wicquefort, who in 1680-168I published the most important treatise on the ambassador of his time (a re-elaboration of his previous Mémoires) ${ }^{83}$. Wicquefort, in particular, clarified that «the Powers, with respect to an Embassador, are nothing else, than what a Letter of Attorney is in reference to a private Person $»$, and considered ratification not to be necessary in strict legal terms, although he conceded that it could be usefully requested as a proof of the counterpart's good faith ${ }^{84}$ :

\begin{abstract}
Ratification is not an essential part of a Treaty ; which is by so much the more evident, not only because a Treaty is a common and publick Instrument, and the Ratification a private and particular one; but also because a Treaty would be good, and subsist without the Ratification, if it were certain that the Treaty, and he that has made it, would not be disavow'd. [...] As the Civil Laws oblige a private Person to ratify what his Mandatary has done by virtue of his Procurations; so the Law of Nations obliges the Prince to ratify what his Minister has done by virtue of his Powers : especially if the Powers are full and absolute, without any Clause or Condition, to limit or restrain the same $e^{85}$.
\end{abstract}

I8. Admittedly, in the eighteenth century, Cornelius van Bijnkershoek and Emer de Vattel cast some doubt on the automatic validity of treaties after their conclusion, observing that the rulers of their time usually reserved the right to ratify whatever they agents had concluded: while the former accepted this practice based on the idea that custom determined the principal part of ius gentium ${ }^{86}$, the latter noted that, since « sovereigns can not be constrained [...] to fulfill their engagements, it is usual not to consider their treaties as final until approved and ratified by the sovereigns themselves $\gg$, although he went on to affirm that « cogent and substantial reasons are needed to justify a sovereign in refusing to ratify the act of his plenipotentiary $\gg^{87}$. However, Georg Friedrich von Martens would still write, in his Précis du droit des gens moderne de l'Europe fondé sur les traités et l'usage (first published in 1789 , and translated into English

78 See ibid.

79 See J. Bodin, Les six livres de la République, Paris, chez I. du Puis, I583, V.6, p. 818-819.

80 See A. Gentilis, De iure belli libri III (note 74), III.I4, p. 594, transl. De iure belli libri tres, translated by J.C. Rolfe (note 74), p. 362, slightly modified.

8I See H. Grotius, De iure belli ac pacis libri tres, curavit B.J.A. De Kanter-Van Hettinga Tromp, annotationes novas addiderunt R. Feenstra et C.E. Persenaire, Aalen, Scientia Verlag, 1993, III.22.4.I, p. 864 (« [...] obligari eum qui praeposuit etiam si praepositus fecit contra mandata arcana, intra limites tamen publicae functionis $\gg)$, transl. De jure belli ac pacis libri tres, translated by F.W. Kelsey, Oxford/London, At the Clarendon Press/Humphrey Milford, 1925, p. 846. See also ibid., II.II.I2, p. 335. For a more detailed analysis of this case and of Bodin, Gentili and Grotius' opinions, see D. Fedele, Naissance de la diplomatie moderne (note 5), p. 270-276.

82 See S. Pufendorf, De jure naturae et gentium libri octo, Londini Scanorum, Sumtibus Adami Junghans imprimebat Vitus Haberegger, I672, III.9.2, p. 377-378.

83 On Wicquefort, see S. Externbrink, «Abraham de Wicquefort et ses traités sur l'ambassadeur (1676-1682)», in De l'ambassadeur. Les écrits relatifs à l'ambassadeur et à l'art de négocier du Moyen Âge au début du XIX'siècle (note II), p. 405-430.

84 See A. de Wicquefort, L'ambassadeur et ses fonctions, 2 vol., La Haye, Chez Jean \& Daniel Steucker, I680-I68I, I.I6, p. 377, and II.I5, p. 375-403, transl. The Embassador and his Functions, translated by Mr. Digby, London, Printed for Bernard Lintott [...] and sold by Charles King et al., 1716, p. I16 and p. 405-413.

85 See A. de Wicquefort, L'ambassadeur et ses fonctions (note 84), II.I5, p. 376 and 385, transl. The Embassador and his Functions (note 84), p. 405 and 408 (emphasis in the original).

86 See Cornelius van Bijnkershoek, Quaestionum juris publici libri duo, Lugduni Batavorum, apud Joannem van Kerckhem, 1737, II.7, p. 228-234 (on p. $233:$ : [...] nam moribus censetur praecipua pars Juris Gentium »). 
in I802), that « every thing that has been stipulated by an agent in conformity to his full powers, ought to become obligatory for the state, from the moment of signing, without even waiting for the ratification ». In Martens' view, it had only recently (« now ») become common, « not to expose a state to the errors of a single person, [...] that public conventions [...] do not become obligatory, till ratified $\gg^{88}$. As his reflection on the issue reveals, the traditional notion of diplomatic representation, grounded in the notion of private law agency developed by late medieval ius commune jurists, was - at least in theory - still valid at the turn of the nineteenth century. It was only during that century that a new doctrine would arise, and ratification would become a fully free and discretionary act, performed by national Parliaments as the final stage of the treaty-making process ${ }^{89}$.

\section{Dante Fedele}

Chargé de recherche, Univ. Lille, CNRS, UMR 8025 - CHJ - Centre d'Histoire Judiciaire, F-5900o Lille, France

dante.fedele@univ-lille.fr

87 See E. de Vattel, Le droit des gens, London, n.p. [recte Neuchâtel, Abraham Droz], I758, II.I2, § 156, p. I43-I44, transl. The Law of Nations, translated by C.G. Fenwick, Washington, Carnegie Institution, 1916, p. I6I.

88 See G.F. von Martens, Précis du droit des gens moderne de l'Europe fondé sur les traités et l'usage, t. I, Gottingue, chés Jean Chret. Dieterich, 1789, II.I $\$$ 3I, p. 5I, transl. A Compendium of the Law of Nations, translated by W. Cobbett, London, Cobbett and Morgan, Pall-Mall., I802, II.I $\$ 3$, p. 49. See M. Koskenniemi, « Into Positivism : Georg Friedrich von Martens (1756-182I) and Modern International Law », Constellations, 15, 2008, p. I89-207.

89 See J. Mervyn Jones, Full Powers and Ratifications: A study in the development of treaty-making procedure, Cambridge, Cambridge University Press, 1946. 